\title{
Integrating Japanese Local Government and Communities into the Educational Curriculum on Regional Sustainability Inside the UNESCO's Biosphere Reserves and Geoparks
}

\author{
Aida Mammadova (iD \\ Kakuma Machi, Kanazawa University, Kanazawa City, Ishikawa Prefecture 920-1192, Japan; \\ mammadova@staff.kanazawa-u.ac.jp
}

\begin{abstract}
This study analyzes whether biosphere reserves (BR) and geoparks (GP) can serve as platforms to contribute to education for sustainable development by integrating local authorities and communities into the educational process. For two years, we conducted the integrated course named "UNESCO Biosphere Reserves and Geoparks", with a total number of 143 students. The curriculum was carefully designed together with the local government and community members. Both BR and GP increased the awareness and knowledge of regional sustainability and served as educational platforms to integrate the local government and communities inside the academic curriculum. Students replied that their knowledge about the BR and GP was raised by $83 \%$ and $92 \%$, respectively. Practical field trips showed an increased awareness of the locals' efforts towards regional sustainable development. Both BR and GP provided site-specific knowledge and functioned as the learning platform to teach about the linkage of human-nature interaction towards regional sustainable development. Most of the students expressed that BR helped them to analyze the situation at the issue-oriented community level (76\%), whereas GP helped them to think broadly about the relation of humans with the Earth at the global level (89\%).
\end{abstract}

Keywords: biosphere reserve; geopark; education for sustainable development; community; local government; sustainability

\section{Introduction}

Biosphere reserves (BR) and geoparks (GP) are natural sites recognized by UNESCO to conserve the world's biological, geological and cultural diversity and promote sustainable economic development for present and future generations. Education for sustainable development (ESD) is used in both programs to raise awareness, develop skills and attitudes to deal with sustainability issues, such as environmental, social and cultural in relation to people, local communities and other regions of the world. ESD "allows every human being to acquire the knowledge, skills, attitudes and values necessary to shape a sustainable future" [1] and is looking at education as the critical tool for sustainable development. In 1971, UNESCO launched the Man and Biosphere Program (MAB) with the aim to improve the sustainable relationship between people and their environments on a scientific basis. The BR concept was created in 1974 by the MAB program as sites where human-nature interactions are tested, refined, and demonstrated and where the objectives of the MAB program are implemented. Since 1995, all BRs have had three main objectives: conserving biodiversity, which aims to preserve landscapes, ecosystems, species, and genetic variations; promoting sustainable development by fostering social, cultural, and ecologically sustainable economic development to benefit local peoples; and supporting research, monitoring and education [2,3]. To strengthen the global network, the MAB program launched the World Network of Biosphere Reserves, and as of 2020, the number of BRs has reached 701 in 124 countries [4]. The concept of ESD was first reflected inside the Madrid action plan for 2008-2013 [5,6], and this strategy was intended to be an integral 
part of UNESCO's strategy working towards the achievement of a decade for education for sustainable development. During the UNESCO World Conference on ESD in Bonn in 2009, it was stressed that BRs have high values in the ESD process and provide learning spaces for multiple players among communities, researchers, governmental decisions and policymakers and other stakeholders. For 2015-2025, MAB adopted four strategic objectives, and one of which is "facilitate biodiversity and sustainability science, ESD and capacity building" [7]. In 2016, to create the actual roadmap to reach MAB's strategic objectives, MAB adopted the Lima action plan 2016-2025 (LAP) and highlighted the importance of learning and training for biodiversity conservation and sustainable development. LAP is consisted of 5 strategic action areas, with 62 actions and specific outcomes. In its "strategic action area A," it emphasizes the importance of the partnership between the local authorities and academic institutions for conducting the learning activities inside BRs and strengthening the interface between science, policy, education and training for sustainable development. Especially in point A4.5, it is stated to "encourage managers, local communities and other BR stakeholders to collaborate in designing and implementing projects that inform management of sustainable development of their BR".

Meanwhile, the concept of GP was developed in Europe in 1989 [8], and it refers to a territory, which has a particular geological heritage site of geological significance and a sustainable development strategy for territorial protection [9]. In 2004, UNESCO supported the creation of the global geoparks network (GGN) and later created a new label of UNESCO global geoparks. Geoparks provide information on the history of Earth, and they are also the keepers of archaeological, ecological, historical and cultural values, all of which make them play a significant role in education, science, and cultural and socio-economic development. As of 2020, 161 UNESCO global geoparks in 44 countries are recognized [10]. GP also has a close affinity with ESD by highlighting education as one of the main three pillars of its objectives, together with geoconservation and geotourism [11,12]. GP promotes education at all levels, from university to local communities. Both BR and GP are designed to encourage national governments and local communities to recognize significantly important areas and contribute to the conservation and sustainable utilization of its natural resources for current and future generations [13]. In many cases, BR and GR areas are also designated to examine the positive interaction between people and nature over a long period of time and are functioning as learning sites for sustainable development [14-16]. Functioning as models for sustainable development and as successful learning sites, BR and GP can contribute to the creation of a unique and integrated educational platform where local government, academic institutions and local communities can come together to conduct educational activities towards regional sustainable development.

Outdoor activities and field works have shown to give positive results for environmental education, especially for nature-related studies, biodiversity education and conservation [17-20]. Environmental education with outdoor activities can help create a positive attitude and raise awareness and understanding of the relationship between humans and their environments [21-23] and prevent environmental issues [24,25]. The acknowledgment of the fact that the issue exists can encourage the youth for the personal commitment to work and solve environmental issues [26]. On the other hand, universities have the possibility to provide specific knowledge and know-how, both of which will be converted into social skills and transferred as knowledge to future citizens [27]. Surrounding regions where universities are located often consider universities as important actors who can provide specific expertise and contribute to regional development. In such close connection, universities and regions can support sustainable development and deal with governmental issues more effectively. Regional universities act as supporters of cooperation between regional stakeholders, and they function as key players in regional development processes [28]. This kind of linkage between universities and local authorizes one of the main objectives of MAB's Lima action plan and ESD [29].

However, for many reasons and in many cases, both universities and regions do not fully utilize their potential for cooperation to conduct ESD programs [30,31]. Most of 
the time, academic institutions have their own curriculum created by the educators from the scientific world, and due to the insufficient cooperation, less involvement of local government or communities take part in the educational processes [32]. In this study, we decided to create a unique educational course and integrate the local government and local citizens into the academic processes so that the students were able to directly learn from the local authorities about the BR and GP. Our main questions were:

- Can BR and GP serve as platforms to contribute to ESD by integrating local authorities and communities into the educational process about regional sustainability?

- What kind of site-specific knowledge can each BR and GP provide during the learning processes?

Even though both BR and GP are internationally designated areas with the concept of sustainable development as the core principle to follow, the approaches to reach sustainability in each program are different. Both concepts are strongly related to the ESD $[13,33]$ and have education as the main pillar in their objectives. ESD is not only focused on reacting to the threats from nature to humans but is also intended to modernize society by including as many different stakeholders as possible into the learning process [34], such as government officials, decision-makers, researchers, and local communities.

Our purpose was to find out what kind of site-specific knowledge BR and GP can provide for the students who are learning about regional sustainability according to the curriculum designed together with local authorizes and communities. BR is more about ecosystem management and the conservation of biological and cultural diversity, economic and social development based on local community efforts and sound science generations [35]. At the same time, GP focuses on earth sciences, like geology, which has international value, local community support and a bottom-up approach to the conservation and promotion of geotourism [36]. Some common purposes are also shared between the two programs, such as 1) protection of the natural heritage, 2) research and education activities, and 3) local economic development [13]. In terms of education, GP is used as a pedagogical tool for environmental education related to geoscientific disciplines, global environmental issues and sustainable development [37], and they explore methods of conserving geological heritage, such as the conservation of rocks, mineral resources, fossils and landforms. BRs are used to teach about the harmonious co-existence of humans with the surrounding nature and rational utilization of the natural resources. They demonstrate how the ecosystem provides crucial services for humans' livelihoods, like clean water, food, soil and cultural values created from nature, and they can also be utilized to study social-ecological resilience [38]. Both BR and GP provide an opportunity to reach the educational objectives of ESD, such as provide information, knowledge and awareness about environment-social issues; change behavior, attitudes and values towards nature and society; and acquire skills/competencies to tackle issues and provide learners with the opportunities for participation and active involvement for issue-resolving processes [34].

\section{Japanese Mount Hakusan Biosphere Reserve and Hakusan Tedori River Geopark}

Here we focused on the Japanese cases of UNESCO's Mount Hakusan Biosphere Reserve (MHBR) and Hakusan Tedori River Geopark (HTGP), which belongs to the National Geoparks of Japan. We choose those areas, as both designations have the mandate to contribute to the ESD and function as the field to include different stakeholders towards the regional sustainable development.

Both MHBR and TGGP start at the top of the sacred Mount Hakusan and share some overlapping areas. Mt. Hakusan (2702 m) is a volcanic mountain located in the central part of the Japanese archipelago facing the Sea of Japan. The mountain area expands over four prefectures (Ishikawa, Toyama, Giku and Fukui), and in 1969 it was designated as a National Park. Later in 1980, it was designated as a UNESCO Biosphere Reserve by the MAB Program. The total area of MHBR is 199,329 ha, and the population is over 17,000 people. It has a three-zonation system specific for the BRs: a core area $(22,120 \mathrm{ha})$, a buffer area (45,660 ha) and a transition area (131,549 ha) [39]. The core and buffer areas 
are functioning mainly for preservation and research activities, whereas the Transition area is settled and inhabited by the local villagers. The entire Core zone and some parts of the buffer zone are also registered as National Parks of Japan.

The beginning of HTGP was in 2011, when the entire Hakusan City of Ishikawa Prefecture, including the peak of Mt. Hakusan, was approved as a Japanese Geopark. The original concept was designed around the Tedori River, which flows from the top of Mt. Hakusan into the Sea of Japan and forms the entire landscape of Hakusan City [40]. "Follow the journey of water!" is the slogan of this GP. Along the river, this GP has set up a number of geosites (geospots) and divided the entire GP into three areas: Mountain and snow with the Oguchi and Shiramine areas; river and canyon with the Kawachi, Torigoe, and Yoshinodani areas; and the sea and alluvial fan with the Matto, Mikawa and Tsurugi areas.

Presently, the local government management structure for the conservation and sustainable resource utilization of Mt. Hakusan is functioning within several designations like National Park, a Biosphere Reserve and a Geopark, and some others. In this study, we chose BR and GP as fields of our study, as both designations have overlapping territories managed by the local municipality of Hakusan City, and the activities of local communities for sustainable resource utilization are allowed within those territories. To conduct the governmental management, Hakusan City has created two promotion divisions for each program: the Mount Hakusan Biosphere Reserve Council and the Hakusan Tedori River Geopark Promotion Council. At present, the Mayor of Hakusan City is acting as council chair of both systems, and the secretariat is located at the Hakusan City Office. Moreover, the Ministry of the Environment, which is in charge of the management of Hakusan National Park, is also associated with both councils. Both councils are acting according to the concepts of the international initiatives aiming for sustainable development. In addition, both councils emphasize the importance to not only protect but also utilize the natural resources of Mt. Hakusan in a sustainable manner by involving local citizens and enterprises. Geoparks promote those activities through geotourism and bottom-up approaches, and Biosphere Reserves through the harmonized ecosystem management of local's livelihoods. However, both programs include educating, building capacity, raising public awareness and training as priority areas. Our focus was to evaluate the role of the local government and local communities in the creation of an integrated academic curriculum and to investigate the site-specific knowledge provided by both BRs and GP.

\section{Methods and Instruments}

From 2018 to 2020, at K University in Japan, we created the first integrated course named "UNESCO Biosphere Reserves and Geoparks" as part of the curriculum to teach about regional sustainable development. Each academic year of the course was divided into two semesters: spring (April-June) and autumn (October-March). The total number of students who attended the courses for 4 semesters was 143 . All students were university undergraduates, with an average age of \pm 23 years old, and with gender differences as Female 59\% (n-84) and Male 41\% (n-59). All students had different backgrounds with majors in Human and Social Sciences 57\% (n-81), 32\% (n-46) from Nature and Technology Sciences and $11 \%$ (n-16) from Medical and Pharmaceutical Science (Figure 1).

International and Japanese students took the course together, and $44 \%$ (n-63) of them were from Europe, 31\% (n-45) from Asian countries, 7\% (n-10) from America and Oceania, and $17 \%(n-25)$ were Japanese students (Figure 2).

Before taking the course, we took interviews with the students to clarify that none of them were familiar with the concept of BR and GP. The curriculum of the course was carefully designed together with the representatives of both the MHBR and HTGP promotion Councils of Hakusan City, as well as with the local communities of Hakusan City. Each semester was divided into three parts: Theoretical in-class activities, Practical Observations with overnights, and also self-research and report submission. Theoretical 
and practical activities in their term were divided into two parts: the first related to the studies on BR (6 modules) and the second about the studies on GP (6 modules).

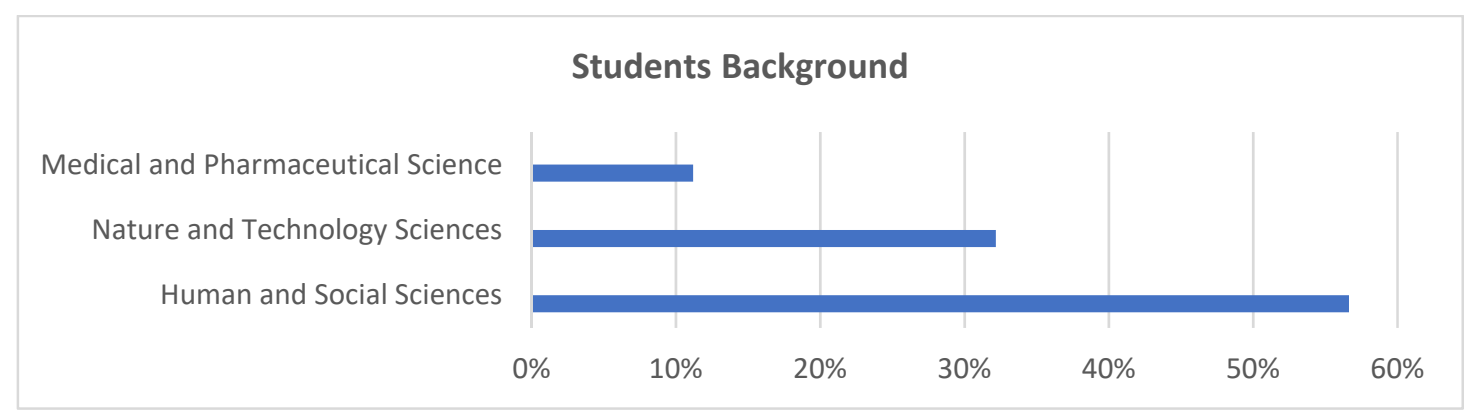

Figure 1. Student majors.

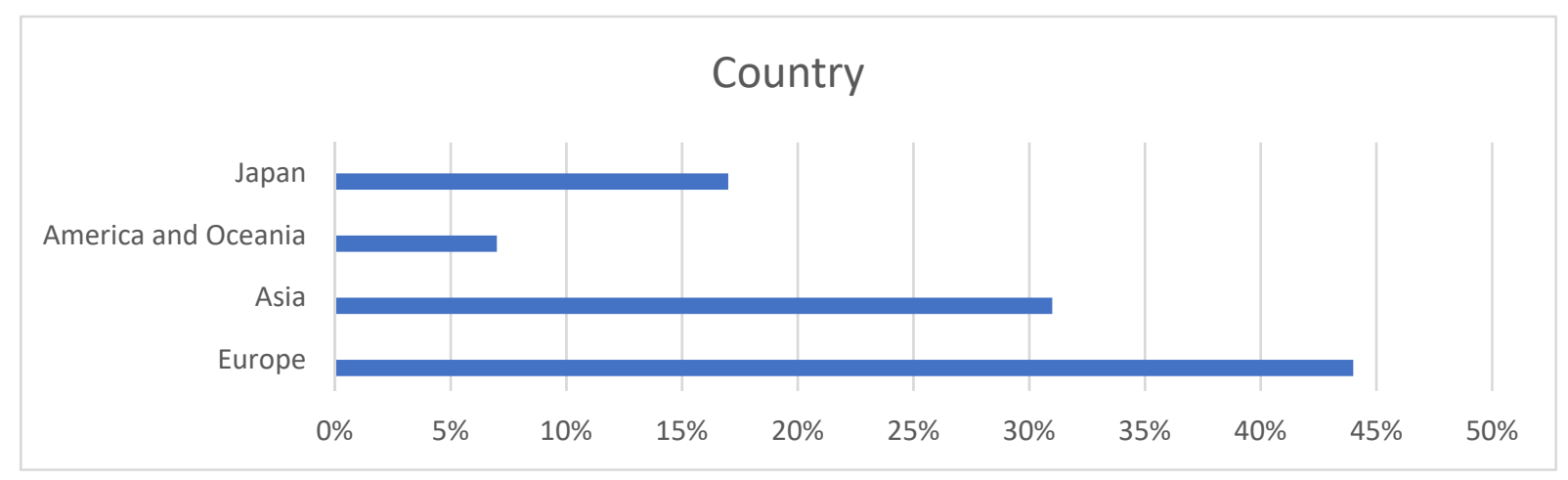

Figure 2. Origin country of the students.

During the theoretical parts on BRs and GPs, the members of the MHBR and HTGP Promotion Councils were invited as lecturers to explain the basic concept of each UNESCO program and local initiative to foster regional sustainable development. The practical part was conducted together with the regional council members and local villagers. At the beginning of each trip, the instructors gave a basic explanation about the regions concerning the landscapes and the ecological and social-economic backgrounds of the region. They also explained the local issues related to depopulation, aging, the effects of global warming and others. Later, students had an experiential practice together with the local communities. All trips lasted for one day or a half-day, were guided by the professional local instructors and educators and were issue-oriented.

Field trips to BR were divided into the following thematic trips: biological and cultural diversity of Shiramine village, forest and wildlife management, scenic town walk and communication with local villagers, traditional food making for winter preservation, winter snow activities, livelihoods and spiritual practice. Field trips to GPs were divided according to the concept of "follow the journey of water" by following the path of the Tedori River, which flows from the top of Mt. Hakusan and forms the entire Hakusan City. Students visited the terrain inside the town of Tsurugi created by deep water, Watagaki Waterfall and Tedorigawa Gorge, and the Torigoe Castle ruins, which is a place located on a mountain elevation between the Tedori and Dainichi Rivers. In the end, they visited a huge rock weighing 4800 tons named Hyakumangan, which washed down from the mountains in 1934. They also visited Kuwajima Fossil Bluff, a site famous for dinosaur fossils that is often called the birthplace of Japanese geology. The details of the field trips are shown in Table 1. 
Table 1. Field trips taken by students in Mount Hakusan Biosphere Reserve (MHBR) and Hakusan Tedori River Geop$\operatorname{ark}$ (HTGP).

\begin{tabular}{llll}
\hline \multicolumn{1}{c}{ MHBR } & \multicolumn{1}{c}{ HTGP } \\
\hline - & Biological and cultural diversity of Shiramine Village & - & $\begin{array}{l}\text { Geological terrain inside the town of Tsurugi created by } \\
\text { deep water }\end{array}$ \\
- & Forest and wildlife management & - & Watagaki Waterfall and Tedorigawa Gorge \\
- & Traditional houses town scenes walk & - & Torigoe mountain elevation between the Tedori and \\
- & Communication with local villagers & Dainichi Rivers \\
$-\quad$ & Traditional food making for winter preservation & - & Hyakumangan Rock \\
- & Winter snow activities and volunteering & - & Kuwajima Fossil Bluff famous for dinosaur fossils \\
\hline
\end{tabular}

\section{Data Collection}

The main tools used to collect the data for this research were questionnaires and report submission. The questionnaire for the course was designed by the members of MHBR and HTGP, as well as local citizens. In addition, during the design of the questionnaire, particular attention was given to former studies that have already been conducted about educational practices on environmental education [41], ESD [34], and several studies have used BR $[34,42]$ and GP $[43,44]$ as tools to conduct environmental education in the learning process. In our study, we decided to combine both tools to conduct a comparative analysis between BR and GP as educational tools and evaluate what kind of site-specific knowledge can those two instruments provide while studying regional sustainability. In addition, the involvement of the local authorities and local communities in questionnaire design was conducted for the first time in BR and GP courses.

The questionnaire consisted of three parts (BR, GP and sustainable development (SD)) and with two subparts of theory and practice in the BR and GP divisions, according to the course structure (Table 2). In total, students replied to 25 different questions (10 on theoretical courses of BRs/GPs, 10 on practical courses BR/GP, and 5 questions on SD). The theoretical analysis was conducted to evaluate the overall impression of the lectures provided by the local authorities, while the practical part was done to get the reflection of the students on regional sustainability. During the SD questions, students were required to find the site-specific element, which will be related to a particular program of BR or GP. This was done to compare the particular site-specific knowledge provided by BR or GP. Several trials to evaluate the accuracy of the questionnaire were conducted with a group of experts, and it was refined into its final version. Questionnaires were collected after the completion of each semester. In total, the questionnaires for 4 semesters from 143 students were collected and analyzed. All data were stored at K University and is available from the corresponding author on reasonable request.

Table 2. Questionnaire structure with the objectives of the questions.

Questionnaire Structure
5 questions on the theoretical part of the course
(evaluate the overall impression of the lectures)
5 questions on the practical part of the course
BR (10 questions)
(evaluate overall awareness / knowledge after the outdoor activities)
GP (10 questions)
5 questions on the theoretical part of the course
(evaluate the overall impression of the lectures)
5 questions on the practical part of the course
SD (5 questions)
(evaluate overall awareness/knowledge after the outdoor activities)

Knowledge and awareness on the BR and GP programs were measured and scored as $1=$ very bad, $2=$ bad, $3=$ neutral, $4=$ good, $5=$ very good. Attitudes towards the 
course were measured by a Likert scale of five ratings: $1=$ strongly disagree, $2=$ disagree, $3=$ neutral, $4=$ agree, and $5=$ strongly disagree. The closed-ended questions and multiplechoice questions were also collected with yes/no replies. At the end of the questionnaire, there was an open field allowing participants to add free comments. After course completion, all students were required to submit the reports and to answer questions about 1) how the theoretical and the practical parts of the course provided by the governmental council members and locals helped them to recognize the concept of BRs and GPs towards sustainable development and 2) the merits and demerits of the course.

\section{Results}

The entire courses organized together with the members of the local councils and local communities were highly appreciated by the students as very good and good, $89 \%$ for BR and $92 \%$ for GP. Students replied that all lectures and field trips were systematically organized ( $90 \%$ for BR, $87 \%$ for GP), and their knowledge about the local BR and GP was raised for $83 \%$ and $92 \%$, respectively (Table 3 ).

Table 3. Overall evaluation of the course.

\begin{tabular}{ccc}
\hline Overall Evaluation of the Course & BR & GP \\
\hline $\begin{array}{c}\text { Was the course systematically and comprehensively organized? } \\
\text { (sum of the "agree" and "strongly agree" replies) }\end{array}$ & $89 \%$ & $92 \%$ \\
\hline $\begin{array}{c}\text { Did the theoretical and practical part provide adequate knowledge and information? } \\
\text { (sum of the "agree" and "strongly agree" replies) }\end{array}$ & $90 \%$ & $87 \%$ \\
\hline $\begin{array}{c}\text { Was awareness raised about both programs? } \\
\text { (sum of the "agree" and "strongly agree" replies) }\end{array}$ & $83 \%$ & $92 \%$ \\
\hline
\end{tabular}

After the practical field trips, all students expressed an increased awareness about local citizen and government efforts towards regional sustainable development; however, for GP, those efforts were higher (88\%) than for BR (73\%). Students also noticed that the concept of BRs had weaker recognition by the locals (65\%), but the GP concept was much more familiar to the local communities $(88 \%)$. For the question about how well they understood the locals' regional issues after the courses, the replies were $89 \%$ for BR and $76 \%$ for GP (Table 4$)$.

Table 4. Evaluation of the relationship between government and locals.

\begin{tabular}{ccc}
\hline Evaluation of the Relationship between Government and Locals & BR & GP \\
\hline $\begin{array}{c}\text { Did the course increase awareness about the efforts of local } \\
\text { government to work towards sustainable development? }\end{array}$ & $73 \%$ & $88 \%$ \\
\hline How well do local people recognize two programs? & $65 \%$ & $88 \%$ \\
\hline Has the course increased awareness about local's issues? & $89 \%$ & $76 \%$ \\
\hline
\end{tabular}

After the field trips to BR, the knowledge between the human-nature-economic development was raised in the students (86\%), and GP showed an increased knowledge towards the geological characteristics of the region and its linkage with the humans (93\%) (Table 5). BR was more related to the traditional livelihood practices and management of ecosystem services ( $86 \%$ ), while GP was related to sustainable development through the promotion of geotourism and educational activities (92\%). For the question about what program helped them to understand the concept of sustainability, $93 \%$ replied for BR, and $72 \%$ replied for GP. Most of the students expressed that BRs helped them to deeply analyze and consider the situation at the issue-oriented community level $(76 \%)$, whereas GPs helped to think broadly about the relation of humans with the Earth at the global level $(89 \%)$. 
Table 5. Evaluation of sustainability and site-specific knowledge.

\begin{tabular}{|c|c|c|}
\hline Evaluation of Sustainability and Site-Specific Knowledge & BR & GP \\
\hline Which course raised awareness on the link between human-nature-economy development? & $86 \%$ & $75 \%$ \\
\hline Which course raised awareness on the link between geological features and human wellbeing? & $65 \%$ & $93 \%$ \\
\hline Which course increased awareness of ecosystem services and traditional livelihoods? & $86 \%$ & $76 \%$ \\
\hline Which part of the program is suitable to promoted tourism and education? & $80 \%$ & $92 \%$ \\
\hline Which program provides knowledge of the concept of sustainability? & $93 \%$ & $72 \%$ \\
\hline \multicolumn{3}{|l|}{ What is the site-specific knowledge provided by each program? } \\
\hline Knowledge of issue-oriented communities & $76 \%$ & $56 \%$ \\
\hline Knowledge on human-earth co-existence & $69 \%$ & $91 \%$ \\
\hline
\end{tabular}

In addition, from the submitted reports, it was found that some students $(26 \%)$ expressed that they were confused by the two programs because they found the purposes of the BR and GP to be too similar.

\section{Discussion}

According to UNESCO's mandate, both BR and GP programs are required to be operated based on scientific knowledge and to contribute to ESD and research. Therefore, it is essential to create a close collaboration between the local authorities and universities to contribute to the successful development of the programs on a win-win basis.

Japanese academic institutions make great efforts to build a sustainable society, and these requirements are placed inside Japan's national curriculum standards. Japan was one of the countries, who promoted the ESD at the governmental level, and in Japan's basic plan for the promotion of education, ESD is positioned as mainstream policy across Japan's education system [44]. In 2006, the Japanese government created an implementation plan to promote the United Nations Decade of ESD (2005-2014) and stated that "the objectives of ESD are to bring about a transformation of behavior that enables the realization of a sustainable future, in environmental, economic, and social terms, in which all people can enjoy the benefits of high-quality education and in which the principles, values, and behavior required for sustainable development are incorporated into all education and learning situations, resulting in a transformation into a sustainable society" [45]. However, sustainability is a broad field and needs an interdisciplinary approach with the involvement of different stakeholders in curriculum development. In many cases, curriculums for the education for sustainable development are made by academic research and professors and lack effective cooperation with local government and local communities [30] (Glavič, 2020). If organizational operations are transformed, and academic content related to sustainability and community development is maximized, along with, including multiple stakeholders, then ESD could motivate learners to achieve a sustainable society $[46,47]$. ESD aims to empower and prepare younger generations to meet their needs by using holistic and integrated approaches to the economic, social and environmental aspects of sustainable development. Moreover, ESD is focused not only on reacting to the threats from nature to humans, but it is also intended to modernize society by including as many different stakeholders as possible in the learning process [34]. Complying with the concept of ESD, both BR and GP permit the inclusion of sustainable development issues inside the learning and teaching processes while providing young people with participatory skills and motivation to change their behavior through acquired knowledge and new values, all to take action for regional sustainable development.

From 2015, UNESCO announced the global action program (GAP) on ESD, with five priority action plans, one of which is to encourage local communities and municipal authorities to develop community-based ESD programs. GAP stresses strengthening learning opportunities by involving the local authorities and municipality leaders, academic institutions, NGOs, etc., private sectors to be involved in the integrated and participatory 
learning, which will further contribute to the action empowerment [48]. At the same time, MAB's strategic objectives with LAP highlight that BR must serve as ESD hubs, and ESD activities must take place in all BR [7]. According to the concept of ESD and LAP, we can see the strong necessity to link the ESD activities together with local authorities and communities inside BR and GP. Japan at the national level supported ESD implementation at all educational sectors, and many universities have implemented ESD-related programs and activities [49], however, initially, they were related to environmental education [50], and less emphasis was given to the role of local communities. The involvement of local communities in the ESD started when the ministry of environment requested to develop models of higher education programs by using multi-stakeholder approaches and include private companies, NGOs and communities.

One of the main questions of our study was to find out the role of local authorities and communities to contribute to ESD by using the BR and GP as the models for learning. We were able to show that the educational courses conducted by the local authorities increased the knowledge not only towards the BR $(90 \%)$ and GP $(87 \%)$ programs (Table 3$)$ but also about the issues of the local communities towards sustainable development (BR $89 \%$, GP 76\%) (Table 4). The academic institutions in Japan make increasing efforts to work together with local government and solve local issues towards the concept of regional sustainable development by creating ESD programs; however, this is still difficult to achieve, as the concept of the ESD is not only about the environmental issues, but is a very broad concept with multiple tasks, which includes economy, society and environment [51], and requires the involvement of multiple-stakeholders with interdisciplinary approaches. In addition, the relationship between universities and local authorities is not always running smoothly and sometimes creates many confusions in the educational management processes [52,53]. This study showed that BR and GP served as an effective platform to teach about ESD by involving diverse stakeholders and educators in the program. We found that BR and GP provided differences in learning about sustainability, as $93 \%$ of the students replied that the concept of sustainability was more easily understood from the BRs programs than the GPs program (72\%). This was related to the fact that the concept of sustainability is very closely related to humans' interaction with nature [34], and BRs provided more practical field trips related to humans' livelihood and ecosystem services $(86 \%)$, whereas GPs provided many field trips related to the geological characteristics and human wellbeing (93\%) (Table 5).

Some students also noticed several similarities between both programs with common goals $(26 \%)$ and were confused with the similarities in the concepts. This is because the general concept of these two programs is essentially inseparable. Ecological diversity cannot exist without geological diversity, and ecosystem services used by humans are provided by geo-diversity. Even though the concepts are similar, the management structure between the organizing committees is different, and it was noticed during the field trip activities, as BR provided wider opportunities to communicate with local communities, whereas GP was much more scientifically oriented and emphasized the development of tourism.

After communication with the locals, students found that the concept of GP was much more popular $(88 \%)$ than the BR $(65 \%)$ was with the local villagers (Table 4$)$. This was due to the efforts of the local authorities and the Hakusan City's Tourism Promotion Division to advertise the geotourism inside the HTGP by educating the local residences to work as the guides, creating the guidebooks, establishing the guide signs, etc. [54]. Since the entire Hakusan City is a Geopark, it provides priorities for the local municipal authorities to have their own decision-making rights. This is completely different from MHBR, which has a multi-governmental structure consisting of four prefectures and seven municipalities, and management actions towards these BRs must be taken with consent from other authorities [55]. However, both programs are using education as a means of conservation for both biological and geological heritage through activities, such as 
creating the teaching resources, supporting the field trips, developing the websites, holding scientific conferences, and promoting school visits.

Both BR and GP have a clear mandate to function as tools to improve education quality towards regional sustainability and emphasizes the partnership between the local authorities and academic institutions to achieve these goals. This is especially pointed in the MAB's Lima action plan on BRs. BR was meant to be the place to preserve the genetic material of natural areas and served as an important research area for scientists to study the ecosystem. Later, the program was developed to harmonize environmental conservation with regional economic development and humans' livelihoods. Most of the students expressed that BR helped them to deeply analyze and consider the situation at the issue-oriented community level (76\%) (Table 5). This result showed that BRs can be placed to teach about the human-nature interaction at the small community level and raise questions about sustainable livelihoods. Related to the GP, students replied that GP helped them to think broadly about the relation of humans with the Earth at the global level (89\%) (Table 5), and it was consistent with the concept of GPs that they are not only the fields to teach about geology, but they also encompass all-inclusive Earth-human interactions.

\section{Conclusions}

This study has shown two things: (1) BR and GP served as educational platforms to integrating the local government and communities inside the academic curriculum, and both programs increased the knowledge of regional sustainability; (2) both BR and GP have provided site-specific knowledge and functioned as the learning platform to teach about the linkage of human-nature interaction towards the regional sustainable development.

This study contributes to the education for sustainable development, which is not only focused on reacting to the threats from nature to humans but is also intended to modernize society by including as many different stakeholders as possible in the learning process. We have shown a case where local authorities and local communities are involved in the learning processes of BR and GP territories, and the results of this study can contribute to the further positive collaboration between the local government and academic intuitions in conducting education for sustainable development. This finding also contributes to the MAB's Lima action plan, which emphasizes the importance of the partnership between the local authorities and academic institutions on conducting learning activities inside BRs and strengthening the interface between science, policy, education and training for sustainable development.

In addition to contributing to ESD, conducting the learning activities inside BR and GP together with local government and communities have shown to have other several advantages, and here we can give some recommendations on how this study can be beneficial for the society: (1) students can use the relationship created between the local government and the universities for their studies and research; (2) students have a unique opportunity to interact with the local communities and raise the awareness and interest to deal with the locals' issues; (3) direct communication and contact with local government members, helped students to understand more about the governmental management system of Mt. Hakusan and can help with future employment opportunities inside the local municipalities.

However, this study has a limitation, as we did not analyze awareness level before the course on each BR and GP, as well as the level of community engagement into the educational activities of each program. More studies must be conducted in the future to make qualitative and quantitative analyses of each BR and GP course and evaluate the relationship between them, as well as the relationship between the students' majors with $\mathrm{BR}$ and GP.

Both BR and GP have some similar goals, and some students were confused with the common goals; and therefore, in future studies, we can suggest, to make some theoretical and practical corrections in the methodology while conducting BR and GP studies together. 
Funding: This research received no external funding.

Institutional Review Board Statement: Not Applicable.

Informed Consent Statement: Not Applicable.

Data Availability Statement: All data are stored at Kanazawa University and are available from the corresponding author on reasonable request.

Conflicts of Interest: The authors have no conflicts of interest to declare that are relevant to the content of this article.

\section{References}

1. Leicht, A.; Heiss, J.; Byun, W.J. Issues and Trends in Education for Sustainable Development; UNESCO publishing: Paris, France, 2018; Volume 5.

2. Batisse, M. Biosphere reserves: A challenge for biodiversity conservation \& regional development. Environ. Sci. Policy Sustain. Dev. 1997, 39, 6-33.

3. UNESCO Biosphere reserves: "The Seville strategy \& the statutory framework of the world network" Paris. 1996. Available online: http:/ / unesdoc.unesco.org/images/0010/001038/103849Eb.pdf (accessed on 5 November 2020).

4. UNESCO Biosphere Reserves. Available online: https:/ / en.unesco.org/biosphere\#: \{\}:text=There $\% 20$ are $\% 20 \mathrm{currently} \% 20701 \%$ 20biosphere,World\%20Network\%20of\%20Biosphere\%20Reserves (accessed on 15 November 2020).

5. UNESCO Madrid Action Plan for Biosphere Reserves (2008-2013). Paris: UNESCO Division of Ecological and Earth Sciences. Available online: https://unesdoc.unesco.org/ark:/48223/pf0000163301_eng (accessed on 25 December 2020).

6. Ruoss, E. Biosphere reserves as model sites for sustainable development. Prot. Areas Focus Anal. Eval. Proc. Manag. Prot. Areas 2013, 4, 99-114.

7. UNESCO MAB Strategy 2015-2025. Available online: http://www.unesco.org/new/fileadmin/MULTIMEDIA/HQ/SC/pdf/ MAB_Strategy_2015-2025_final_text.pdf (accessed on 15 November 2020).

8. Jones, C. History of geoparks. Geol. Soc. Lond. Spec. Publ. 2008, 300, 273-277. [CrossRef]

9. EGN European Geopark Charter. European Geoparks Network. 2000. Available online: http://www.europeangeoparks.org/ ?page_id=357 (accessed on 15 January 2020).

10. UNESCO Global Geoparks. Available online: http://www.unesco.org/new/en/natural-sciences/environment/earth-sciences/ unesco-global-geoparks/list-of-unesco-global-geoparks / (accessed on 20 September 2020).

11. Henriques, M.H.; Brilha, J.B. UNESCO Global Geoparks: A strategy towards global understanding and sustainability. Episodes 2017, 40, 349-355. [CrossRef]

12. McKeever, P.J.; Nickolas, Z. Geoparks: Celebrating Earth heritage, sustaining local communities. Episodes 2005, $28,274$.

13. Schaaf, T.; Diana, C.R. Managing MIDAs: Harmonising the Management of Multi-internationnaly Designated Areas: Ramsar Sites, World Heritage Sites, Biosphere Reserves and UNESCO Global Geoparks; IUCN International Union for Conservation of Nature and Natural Resources: Gland, Switzerland, 2016.

14. Price, M.F. The periodic review of biosphere reserves: A mechanism to foster sites of excellence for conservation and sustainable development. Environ. Sci. Policy 2002, 5, 13-18. [CrossRef]

15. Stoll-Kleemann, S.; Bender, S.; Berghöfer, A.; Bertzky, M.; Fritz-Vietta, N.; Schliep, R.; Thierfelder, B. Linking governance and management perspectives with conservation success in protected areas and biosphere reserves. Perspect. Biodivers. Gov. Manag. 2006, 1, 40.

16. Azman, N.; Halim, S.A.; Liu, O.P.; Saidin, S.; Komoo, I. Public education in heritage conservation for geopark community. Procedia Soc. Behav. Sci. 2010, 7, 504-511. [CrossRef]

17. Killermann, W. Research into biology teaching methods. J. Biol. Educ. 1998, 33, 4-9. [CrossRef]

18. Prokop, P.; Tuncer, G.; Kvasničák, R. Short-term effects of field programme on students' knowledge and attitude toward biology: A Slovak experience. J. Sci. Educ. Technol. 2007, 16, 247-255. [CrossRef]

19. Ramadoss, A.; Poyyamoli, G. Biodiversity conservation through environmental education for sustainable development-a case study from puducherry, India. Int. Electron. J. Environ. Educ. 2011, 1, 1-2.

20. Bentsen, P.; Jensen, F.S. The nature of udeskole: Outdoor learning theory and practice in Danish schools. J. Adventure Educ. Outdoor Learn. 2012, 12, 199-219. [CrossRef]

21. Scribner-MacLean, M.; Kennedy, L. More than just a day away from school: Planning a great science field trip. Sci. Scope 2007, $30,57$.

22. Hafezi, S.; SHOBEIR, S.M.; Sarmadi, M.R.; Ebadi, A. A Novel Conceptual Model of Environmental Communal Education: Content Analysis Based on Distance Education Approach. Turk. Online J. Distance Educ. 2013, 14, 154-165.

23. Fuller, I.; Edmondson, S.; Erance, D.; Higgitt, D.; Ratinen, I. International Perspectives on the Effectiveness of Geography Fieldwork for Learning. J. Geogr. High. Educ. 2006, 1, 80-101. [CrossRef]

24. Özden, M. Environmental awareness and attitudes of student teachers: An empirical research. Int. Res. Geogr. Environ. Educ. 2008, 17, 40-55. [CrossRef] 
25. Hungerford, H.R.; Volk, T.L. Changing learner behavior through environmental education. J. Environ. Educ. 1990, $21,8-21$. [CrossRef]

26. Fahlquist, J.N. Moral responsibility for environmental problems-Individual or institutional? J. Agric. Environ. Ethics 2009, 22, 109-124. [CrossRef]

27. Peters, B.G. Concepts and theories of horizontal policy management. In Handbook of Public Policy, 1st ed.; Peters, B.G., Pierre, J., Eds.; SAGE Publications: London, UK, 2006; pp. 115-138.

28. Sedlacek, S.; Gaube, V. Regions on their way to sustainability: The role of institutions in fostering sustainable development at the regional level. Environ. Dev. Sustain. 2010, 12,117-134. [CrossRef]

29. UNESCO Lima Action Plan for UNESCO's Man and the Biosphere (MAB) Programme and its World Network of Biosphere Reserves (2016-2025); UNESCO: Lima, Peru, 2016. Available online: http:/ / www.unesco.org/new/fileadmin/MULTIMEDIA/ HQ/SC/pdf/Lima_Action_Plan_en_final.pdf (accessed on 20 December 2020).

30. Glavič, P. Identifying Key Issues of Education for Sustainable Development. Sustainability 2020, 12, 6500. [CrossRef]

31. Zilahy, G.; Huisingh, D. The roles of academia in regional sustainability initiatives. J. Clean. Prod. 2009, 17, 1057-1066. [CrossRef]

32. Schmidt, L.; Guerra, J.; Nave, J.G. The role of non-scholar organisations in environmental education: A case study from Portugal. Int. J. Environ. Sustain. Dev. 2010, 9, 16-29. [CrossRef]

33. UNESCO Education for Sustainable Development. 2019. Available online: https://en.unesco.org/themes/education-sustainabledevelopment (accessed on 15 September 2020).

34. Scoullos, M.; Kouroutos, V.; Mantzara, B.; Alempei, I.; Malotidi, V. Education for Sustainable Development in Biosphere Reserves and Other Designated Areas. A Resource Book for Educators in South-Eastern Europe and the Mediterranean; United Nations Educational, Scientific and Cultural Organization: Paris, France, 2013.

35. Ishwaran, N.; Persic, A.; Tri, N.H. Concept and practice: The case of UNESCO biosphere reserves. Int. J. Environ. Sustain. Dev. 2008, 7, 118-131. [CrossRef]

36. Farsani, N.T.; Coelho, C.; Costa, C. Geotourism and geoparks as novel strategies for socio-economic development in rural areas. Int. J. Tour. Res. 2011, 13, 68-81. [CrossRef]

37. Gray, M. Geodiversity: Valuing and Conserving Abiotic Nature; John Wiley \& Sons: Hoboken, NJ, USA, 2004.

38. Schultz, L.; Lundholm, C. Learning for resilience? Exploring learning opportunities in biosphere reserves. Environ. Educ. Res. 2010, 16, 645-663. [CrossRef]

39. Iida, Y.; Nakamura, S. Mount Hakusan Biosphere Reserve: Creating a New Path for Communities and Nature; United Nationas University Institute for the Advanced Study of Sustainability, Operating Unit Ishikawa/Kanazawa: Ishikawa, Japan, 2016.

40. Hibino, T.; Nakamura, S.; Aoki, T. The geo-story of Hakusan Tedorigawa Geopark Journey of water. In Proceedings of the General Meeting of the Association of Japanese Geographers Annual Meeting of the Association of Japanese Geographers, October 1 2014; The Association of Japanese Geographers: Tokyo, Japan, 2014; p. 148.

41. Athman, J.A.; Monroe, M.C. Elements of Effective Environmental Education Programs. 2001. Available online: http://www.rbff. org/educational/BPE3.pdf (accessed on 25 December 2020).

42. Marks, M.; Chandler, L.; Baldwin, C. Environmental art as an innovative medium for environmental education in Biosphere Reserves. Environ. Educ. Res. 2017, 23, 1307-1321. [CrossRef]

43. King, C. The international geoscience school syllabus and its development. Episodes 2015, 38, 57-74. Available online: http: / /52.172.159.94/index.php/epi/article/view/63810/49820 (accessed on 15 November 2020). [CrossRef]

44. Henriques, M.H.; Tomaz, C.; Sá, A.A. The Arouca Geopark (Portugal) as an educational resource: A case study. Episodes 2012, 35, 481-488. [CrossRef] [PubMed]

45. Maruyama, H. Education for Sustainable Development (ESD) in Japan. 2010. Available online: www.nier.go.jp/English/ EducationInJapan/Education_in_Japan/Education_in_Japan_files/201103ESD.pdf (accessed on 30 June 2014).

46. Kriesel, J. Education for sustainable development in the biosphere reserves Schaalsee, Germany, and Kristianstads Vattenrike, Sweden. Ph.D. Thesis, Diploma Thesis, University of Greifswald, Greifswald, Germany, 5 June 2012. Available online: http://www.mnf.unigreifswald.de/fileadmin/Geowissenschaften/geographie/angew_geo/Diplomarbeiten/Janin_Kriesel_ Diplomarbeit_BNE.pdf (accessed on 15 November 2020).

47. Kohmoto, D. ESD (Education for Sustainable Development) and education on geoparks. J. Geogr. Chigaku Zasshi 2016, 125, 893-909. [CrossRef]

48. UNESCO Global Action Programme on Education for Sustainable Development (2015-2019). Available online: https: / en.unesco. org/gap/priority-action-areas (accessed on 25 December 2020).

49. Nomura, K.; Abe, O. Higher education for sustainable development in Japan: Policy and progress. Int. J. Sustain. High. Educ. 2010, 11, 120-129. [CrossRef]

50. Kitamura, Y.; Hoshii, N. Education for sustainable development at universities in Japan. Int. J. Sustain. High. Educ. 2010, 15, 483-496. [CrossRef]

51. Abe, O. Movement and Challenges of Education for Sustainable Development in Japan. J. Dev. Sustain. Agric. $2011,6,1-7$.

52. Nakatsuka, M.; Odaigiri, T. Reality and Challenges in Community-University Partnership. J. Rural Plan. $2016,35,6-11$. (In Japanese) [CrossRef]

53. Saio, N.; Ohta, M.L. Local Governments' Stance and Problem on Collaboration with Universities. J. Rural. Plan. Assoc. 2016, 35, 22-26. (In Japanese) [CrossRef] 
54. Hakusan City Webpage, Hakusan Tedorigawa Geopark. 2020. Available online: http://www.city.hakusan.ishikawa.jp/ kankoubunkasportbu/geopark/geo/GEO.html (accessed on 15 November 2020). In Japanese.

55. Tanaka, T.; Wakamatsu, N. Analysis of the governance structures in Japan's biosphere reserves: Perspectives from bottom-up and multilevel characteristics. Environ. Manag. 2018, 61, 155-170. [CrossRef] [PubMed] 